\title{
Economic Analysis of the Influence of Rose Cultivation on Agricultural Economic Growth
}

\author{
Jaidhar. D \\ Assistant professor, Department of Economics, Government Arts College, Dharumapuri-636705, Tamil Nadu, India
}

\begin{abstract}
Rose cultivation provides means of earning to millions of people. Rose cultivation is one of the most labour intensive and additional income generating sector of the economy. Rose is primarily produced for ornamental and decorative Purposes but now it has multifarious and uses. rose is a basic raw material for the Extraction or distillation of rose water, rose oil, gulkand etc. rose water has been valued from ancient times for use in eye drops for its smoothing qualities. Even today rose water is used in eye-lotions. At marriages and other social functions junction rose water is sprinkled on the guests and is also used in drinking water. Rose Oil (ottoof roses) has medicinal property and is often used in Ayurved and rose oil is most costly oil. Dried rose petals called pankhuri. are used during the hot water for preparing cold drinks. Rose lip (fruit) is black in color and good source for vitamin-C.
\end{abstract}

Keywords: Rose, economics, Cost and returns, employment

\section{Introduction}

Rose has greater commercial importance in modern times because of their increasing use worships VIP receptions, public functions funeral processions.

There is a very good demand for cut flowers in the European and gulf countries. They have good export potential this source of foreign exchange earing. Marketing of rose in the European countries accomplish three types of trade. sale in market as cut flowers trade which includes bouquet, garlands for decoration and worship in temples covers a big part of the produce. As far as domestic trade is concerned small manufactures of gulkand buy the flowers from the market when the luxury hotels also have a steady and a seasonal component in. It sivaramane. et, al (2008 and sudha2011) It is one of the fastest growing segments of horticulture, having potential for providing enhanced returns to farmers besides providing employment opportunities especially to woman. (singh, 2009) therefore the government of India has identified floriculture as a focus are for development, Presently, India is the second largest producer of flower after china. (Tamil Nadu stands first in India in the area under flower cultivation 0.25 lakh) ( $\mathrm{He}$ as well as production of loose flowers lakh tones). the production of flowers under diverse agro-climatic and socio economic conditions has given rise to many issues related to growth and instability, productivity differences costs and returns, efficiency, equity and employment in flower, production in Krishnagiri districts formed the university of the study with regard to selection at block, thali was purposively selected, since area wise. It occupied the first position among the various blocks of Krishnagiri districts. The reference year for the study was the agriculture year(2019-2020).

\section{Objective of the Study}

The General Objectives of This Research Work is a Study the Economics of Rose Cultivation This Specific Objectives are;
1. To Analyze the Trend in Area Production and Productivity of rose in Tamil Nadu

2. To Analyze the Economics of Rose Cultivation in The study are

3. To analyze the problems faces by the formers in production of rose cultivation suggest suitable police measures.

Primary data;

Multi stage stratified random sampling methods was adopted for the study. The Krishnagiri districts formed The universe of the study the blocks in the district forms the first stage unit out sampling. The villages in the selected block formers the second stage and the rose growers in the selected villages formed the third and ultimate unit out of the sampling rose cultivation in all the districts of Tamil Nadu krishnagiri districts was purposively selected for the study since it occupies the first position in rose cultivation there are 10 blocks Krishnagiri district namely 1. bargur, 2. Hosur, 3. kavavipattinam, 4. kelamangalam, 5. krishnagiri, 6. mathur, 7. shool agiri, 8. thally, 9. uttangarai, 10. veppanapalli, After arranging the blocks in the Descending order of magnitude based on the area under rose cultivation. The block namely They which occupies the first position was selected and formed the first stage unit of sampling. Thallyblock consist of thally of 53 panchayat villages following the same procedure aslike in the selection of sample block, the first five villages Anchayat, Belagondapalli, Devaganapalli, Jawalagiri, Kempatti were selected for the present study The list of rose cultivation from the five selected villages were collected from the records of the village administrative office. from the list 20 cultivators from each village were selected at random are totally 100 rose cultivators were selected from the five selected village. the sampling distribution of farmers in the selected villages is given in table 1 taking into consideration the purpose and data requirement of the study the period of the study was restricted to agriculture year 2019-2020.

Primary data 
The primary data was collected through personal interview using well structural and pre tested interview scheduled the interview schedule for the study was designed considering physical.

Table 1: The sampling distribution of farmers in the selected villages

\begin{tabular}{|c|c|}
\hline Village & Number of cultivators \\
\hline 1. Anchetty & 20 \\
\hline 2. belagondapalli & 20 \\
\hline 3. Devaganapalli & 20 \\
\hline 4. Jawalagiri & 20 \\
\hline 5. Kemapatti & 20 \\
\hline Total & 100 \\
\hline
\end{tabular}

Cultural and socio economic environmental of farming community in the study are the schedule was pretested and finalized the interview schedule for farmers covered aspects such as general farm and household characteristics Cost at cultivation of rose cultivation and the problem faced in rose cultivation.

Tools of Analysis;

Cost of Cultivation;

Sivaramaneand Sudha-(2011) categorized and estimated different costs as involved in cultivation an annual cultivation as cost $\mathrm{A} 1$ cost $\mathrm{A} 2 \operatorname{cost} \mathrm{B}$ and cost $\mathrm{C}$.

Cost A1;

It consists of all actual expenses in cash and kind incurred in production by the owner operator. It Include expenses incurred on human Labour, bullock labour, machine Labour manure, and fertilizer, plant protection chemicals, Irrigation charges, interest on working capital, depreciation on capital assets and land tax.

\section{Cost A2;}

Cost A1 plus rent paid for leased in land.

Cost-B;

Cost A2 plus Imputed rental value of owned land plus interest on fixed capital.

Cost-C;

Cost B plus imputed value of family Labourcost-C id the total cost of cultivation or gross cost.

Net income;

Gross return minus cost-C.

Methods of measurement of variable;

1. Land; To include the share of land in the total cost cultivation the Imputed, rental valve of owned land in the respective villages were considered for leased in land, the actual rent paid was taken into account.

2. Human Labour; The human labour was measured in terms of man days equipment, the permanent labour, hires labour and family labour ware treated alike and converted in to common physical units in terms of man day equivalents of eight hours.
3. Casual labour wages; The wages paid to the casual labourers were calculated on the basis of the actual cash and valve of kind paid to him per day.

4. Permanent labour wages; the wages of permanent labourers were worked out by dividing the total payment made to them in cash and kind during the year by the actual number of days worked in the form during the same period.

5. Family labour wages; the wages for family labour ware computes on the basis of the wages payment made to the permanent labors

6. Bullock Labour; owned and labour was measured in per hour units and was shared at the prevailing wage rates in the respective villages.

7. Seeds, manures, fertilizers, and pesticides; seeds, manures, Fertilizers and pesticides made valued at actual prices paid for them in the market including the incidentals, the ongoing market rate was imputed for farm produced manure.

Cost of production per unit;

Cost of production per Yonne of rose cultivation was arrived at by dividing the het cost of cultivation per acre by the total per acre yield of rose cultivation in tones.

Cost of production $=$ cost of cultivation value by production Yield $\backslash$ acre

Returns per Rupee;

Returns per rupee was obtained by dividing the gross returns by cost of cultivation per acre

Returns per rupee $=$ gross returns Cost of cultivation

Garrett ranking technique;

The respondents were asked to rank their problems in rose cultivation. in Garrett's ranking technique which ranks ware converted into percent position be using the formulae.

Present position $=(100 \times R i j-0.5) \mathrm{Nj})$

Where $\mathrm{Rij}=$ ranking given to the lit attribute by the $\mathrm{F} 1$ Individual $\mathrm{Nj}=$ number of attributes ranked by the $\mathrm{Jth}$ Individual.

By referring to the Garrett's table, the percent positions estimated were converted into scores thus, for each factor the scores of various respondents ware added and the mean values ware estimated. The mean values then obtained for each of the attributes ware arranged in descending order, the attributes the highest mean value was considered as the most important one and the other followed in that order.

\section{Results and Discussion}

Production and productivity and major area, flower cultivating districts (entrance estimates) 2017-2018.

The total is production and productivity of rose in Tamil Nadu diving the period of 2017-18). 
Table 2: Area production, and productivity and major flower cultivating district (advance estimates-2017-18)

\begin{tabular}{|c|c|c|c|c|c|}
\hline S. N & Name of crop & Area (ha) & $\begin{array}{c}\text { Productivity (M. } \\
\text { T) }\end{array}$ & Productivity (M. T/ha) & Major flower growing districts \\
\hline 1 & jasmine & 13.610 & $1,20,591$ & 8.86 & Madurai, Dindugal, erode, Thiruvallur and Tirunelveli \\
\hline 2 & Chrysan Themum & 5.836 & $1,40,864$ & 17.97 & $\begin{array}{c}\text { Dharmapuri, Salem, Krisnagiri, Dindugal, } \\
\text { Thiruvannamalai. }\end{array}$ \\
\hline 3 & Tubue rose & 4.979 & 65,969 & 13.25 & Dharmpuri, Madurai, salem, Thiruvallurand dindugal. \\
\hline 4 & Mari gold & 2.761 & 72,389 & 26.22 & Krishnagiri, Dharmapuri, Tiruchi and Cuddalure \\
\hline 5 & Rose & 2.088 & 66,971 & 32.07 & $\begin{array}{c}\text { Dharmpuri, krishnrgiri, Dinduga 1, Thanjavur and } \\
\text { Thiruvallur }\end{array}$ \\
\hline
\end{tabular}

Source office of the Assitance Director of statastics krishnagiri.

And 2017-18 reveal that there is a resanable increase wilt them year which is appreciable.

Cost of cultivation of rose flowers;

The cost of cultivation was worked out based on raja and key concept and details on cost and returns are furnished in that table 3 for the land preparation 4 men laboures and 3 women labourers ware used at the wage rate of RS 500 and RS 250 per labour which was estimated as RS 2750 per are in the preparation stage. Tractor was used for ploughing and this hiring charger for one hour ploughing for one was RS-1300 form yard man are was the only organic manure used for production of rose cultivation 2 tones per are at the cost of RS 800 tomes was applies. Which was estimated as RS 1600 per are for the application of organic manures man labour was used wilt the wage rate of RS 500 urea single super phosphate and potash ware the main fertilizers used for production of rose cultivation in the ratio of $32: 16.16 \mathrm{KG}$ per acre. which cost RS 10 per KG RS 12 per KG and 16 per KG respectively and it accounted to RS 300 RS 225 and RS 200 per acre for the application of fertilizer. I men labours was used at the rate of RS 500.

Jasmine and chrysanthemum ware the two plant producing chemicals used for rose cultivation. it was sprayed only once during the growing period of rose cultivation which cost RS 450 and 300 per acre respectively one men labour was used for spraying the plant production chemical wilt the wage rate of RS 500 the crop was irrigated 3 times and for every irrigation one man labour was used at the wage of RS 500 per labour ware used for breeding at the rate of RS 250 per labour which was estimated RS 750.

Two woman labourers ware used for harvesting at the rose of RS 250 per labour interest on working capital was estimated at the rate of 7 percent. It worked out to RS 620 depreciation on fixed capital was 550. since rose cultivation was done in own land by all respondents. rent paid for leased in land was excluded rental value of owned land was excluded rental value of owned land was estimated as one third of the value of output as RS 1000 per acre summation of cost B and family labour wages was considered as cost land it was RS.

Table 3: Cost of cultivation of rose flower (RS/acre) Plant production chemical

\begin{tabular}{|c|c|c|}
\hline Input & Quantity with unit & Cost (RS) \\
\hline \multicolumn{3}{|l|}{ Land preparation } \\
\hline (a) Human Labour & 4 men labRS500 3 women lab x RS 250 & $\begin{array}{c}2000 \\
750\end{array}$ \\
\hline (b) tractor Ploughing & I hrs x RS-1300 & 1300 \\
\hline Organic manure (FYM) & 2 tones $x$ RS 8001 men lab x RS-500 & 2100 \\
\hline Inorganic fertilizers & Rs-750 1men lasxRs-500 & 1250 \\
\hline & 1 spray x1 men Lab Rs-500 & 500 \\
\hline Irrigation charges & 4 times $x 1$ Labx 500 & 2000 \\
\hline Weeding charges & 1 times $\mathrm{x}$ 4womans Lab x Rs1000 & 1000 \\
\hline Harvesting & 1acrexRs1000Rs4womans Lab x250 & 1000 \\
\hline Other miscellaneous expanses & & 500 \\
\hline Sub total & & 12,400 \\
\hline In test on marking Capital & & 1771.42 \\
\hline Depreciation of fixed capital & & 550 \\
\hline Cost A1 & & 14,721 \\
\hline Rent paid for loosed in land & & Nil \\
\hline Cost A2 & & 14,721 \\
\hline Rant value 07 owned land & $1 / 3$ value of output & 4,907 \\
\hline In test fixed capital & & 5000 \\
\hline Cost B & & 24,628 \\
\hline Family Labour wages & & 1000 \\
\hline Cost $\mathrm{C}$ & & 25,628 \\
\hline Yield $(\mathrm{Kg})$ & & 233 \\
\hline Output Rs/Kg & & 300 \\
\hline Gross return & & 69,900 \\
\hline Net return & Gross Income & 44,272 \\
\hline Returns per rupee & Gross Income Cost C & 2.72 \\
\hline
\end{tabular}


Considered as cost $\mathrm{c}$ and it was RS 25, 628 per acre. The average estimated yield of rose flower was $233 \mathrm{KG}$ per acre. Whereas average sale price was, RS 300 per KG the gross return was estimated as RS 69, 900 was RS 44, 272 per acre. The cost of production of $1 \mathrm{KG}$ of rose cultivation was RS 1099.90 and the returns per rupee worked out to 2.72 .

\section{Policy Suggestion}

The estimation of cost of cultivation reveled that cultivating rose flower is a profit are venture also since in recent year rose flower commands a better consumer preference. The government extension agencies may take steps to promote and enhance the cultivation of rose flower cultivation price fluctuation is perceived as the foremost problem in rose cultivation. Government should take needed steps for stabilizing the price by a permanent regulatory mechanism rose cultivation could even be considered to get included under the guarantee price she me since in recent years rose cultivation commands a better consumer preference.

\section{Reference}

[1] Anonynons2006, Indian Horticulture data base 2006, national horticulture boord ministry of Agriculture, govt of India.

[2] A p e d a, 2008, Flouri culture and seeds accessed on 14 july 2008 in www.apeda.com.

[3] Sivaramane N 1998 sustainability of commercial flouricultur a comparison of open field and hi-tech rose cultivation around Bangalore. MSC C asiacultivation around Bangalore. MSC (agricultural cultural Economics) thesis submitted to university of agricultural sciences Bangalore, Karnataka, india.

[4] Singh D. R and R. P singh (2006) structure determinants and efficiency of ground water markets in western uttarpradesh agricultural economics research review $10(1)$; 129-144

[5] C prabakar and 4 shelton peter (2020) an Economics analysis of on the cultivation of sorghum WRT Dindugul of Tamil Nadu Journal of plant Archives No.20 No.2, 2020 PP 4972, 4976.

[6] Shah Deepak "Assessing Economics of jasmine cultivationin India

[7] "Gokhale Institute of politics and Economics 9 July 2007. An ECONOMIC Analysis of rose cultivation on in Krishnagiri district of Tamil Nadu.

[8] Singh, Vinay Kumar. "RURAL EMPLOYMENT PROGRAMME IN BIHAR: AN EVOLUTION. " IMPACT: International Journal of Research in Humanities, Arts and Literature (IMPACT: IJRHAL) 7.1 (2019) 497-508

[9] PARVEEN, B. WAHEEDA, and KV DIVYA. "ICT TOOLS-A GATEWAY FOR EMPLOYMENT OF ENGINEERING GRADUATES. " International Journal of Educational Science and Research

\section{(IJESR) 7.2 (2017) 101-108}

[10] Al-Edary, Adnan Dawood M., and Wisam Neamah Jaafar. "The impact FDI on economics and social indictors in Pakistan country. " International Journal of Business and General Management (IJBGM) 5.2 (2016): 61-76.

[11]BEG, SANA. "ISLAMIC ECONOMICS: AN ALTERNATE ECONOMIC SYSTEM FOR THE THIRD MILLENNIUM. " International Journal of Business and General Management (IJBGM) 5.5 (2016): 1-12.

[12] YASHODA, K., and T. KALYANI DEVI. "INFLUENCE OF PARENTAL EMPLOYMENT, GRADE AND GENDER ON EMOTIONAL MATURITY OF ADOLESCENTS. " International Journal of Environment, Ecology, Family and Urban Studies (IJEEFUS) 7.4 (2017) 1-6

[13] Jha, B. K., et al. "Yield, water productivity and economics of vegetable production under drip and furrow irrigation in eastern plateau and hill region of India. " International Journal Agricultural Science and Research (IJASR) 7.3 (2017): 43-50 